\title{
Perbandingan Efektivitas Pengobatan Lorazepam Bukal Dengan Diazepam Rektal dalam Tata Laksana awal Kejang pada Anak
}

\author{
Susiana Tendean, Hardiono D. Pusponegoro, Bambang Madiyono
}

Latar belakang. Lorazepam bukal dan diazepam rektal digunakan dalam tata laksana inisial kejang pada anak. Penelitian yang membandingkan efektivitas penggunaan lorazepam bukal dan diazepam rektal sejauh ini belum pernah dilakukan pada anak di Indonesia.

Tujuan. Untuk mengevaluasi efektivitas pengobatan lorazepam bukal dibandingkan diazepam rektal dalam tata laksana inisial kejang pada anak.

Metoda. Penelitian ini adalah uji klinis acak terbuka pada anak kejang berusia 6 bulan6 tahun, sebelum mendapat obat antikonvulsan untuk menghentikan kejang. Subyek penelitian menerima lorazepam bukal atau diazepam rektal berdasarkan randomisasi. Parameter keberhasilan terapi adalah kemampuan obat untuk menghentikan kejang tanpa efek samping yang berarti dan kecepatan obat menghentikan kejang. Efek samping diobservasi setelah pemberian obat.

Hasil. Lorazepam bukal efektif menghentikan kejang pada 18 dari 22 pasien, sedangkan diazepam rektal efektif menghentikan kejang pada 20 dari 22 pasien. Pada penelitian ini didapatkan efektivitas lorazepam bukal sama dengan diazepam rektal ( $\mathrm{p}=0,664 ; 95 \%$ IK $0,71-1,14)$. Diazepam rektal lebih cepat dalam menghentikan kejang $(44,7 \pm 22,1$ detik) dibandingkan lorazepam bukal $(92,2 \pm 53,5$ detik), perbedaan ini secara statistik bermakna $(p=0,002)$. Tidak dijumpai efek samping akibat pemakaian lorazepam bukal maupun diazepam rektal.

Kesimpulan. Lorazepam bukal dan diazepam rektal mempunyai efektivitas yang sama dalam mengatasi kejang namun diazepam rektal lebih cepat menghentikan kejang dibandingkan lorazepam bukal.

Kata kunci: kejang, lorazepam, diazepam, anak

K

ejang merupakan suatu kedaruratan saraf anak yang harus segera ditanggulangi. Semakin lama kejang berlangsung, semakin

\footnotetext{
Alamat korespondensi:

Dr. Hardiono D. Pusponegoro, Sp.A(K).

Divisi Neurologi Depatemen Ilmu Kesehatan Anak FKUI-RSCM, Jl. Salemba 6, Jakarta 10430.

Telepon 021-3149161, Fax. 021-3913982.
}

Dr. Susiana Tendean, SpA sulit untuk dikontrol dan tentu semakin tinggi morbiditas dan mortalitas yang akan terjadi. Penanganan kejang ditujukan untuk menghentikan kejang secepatnya dan mencari faktor penyebab yang melatarbelakangi timbulnya serangan. Pemakaian obat yang tidak tepat dapat mengakibatkan kejang sulit terkontrol. ${ }^{1-3}$

Penggunaan obat golongan benzodiazepin masih menjadi pilihan utama dalam mengatasi kejang karena awitan kerja obat cepat dan mempunyai efek samping yang relatif kecil. ${ }^{4-6}$ Penanganan pasien kejang di 
Departemen Ilmu Kesehatan Anak (RS Dr. Cipto Mangunkusumo) Jakarta menggunakan diazepam rektal apabila akses vena belum terpasang. ${ }^{4,7}$ Penggunaan diazepam rektal mempunyai beberapa kelemahan, antara lain obat sering keluar kembali bersamaan dengan feses, memerlukan tehnik tertentu dalam pemberian obat, dan rasa enggan orangtua jika memberikan obat melalui jalur ini terutama jika pasien sudah menginjak usia remaja. Hal ini menimbulkan pemikiran pemberian obat melalui jalur lain yang lebih nyaman, efektif dan tidak melibatkan akses vena. Jalur pemberian obat anti kejang tersebut melalui penyerapan mukosa bukal..$^{8-10}$ Mukosa bukal mengandung banyak vaskularisasi dan pemberian obat melalui mukosa bukal menyebabkan obat terhindar dari first-pass effect sehingga obat cepat memasuki sirkulasi sistemik. Pemberian obat melalui bukal/sublingual disebut juga dengan oral transmucosal administration, ${ }^{11}$ salah satunya adalah lorazepam bukal.

Lorazepam direkomendasikan untuk mengatasi kejang karena awitannya cepat, mempunyai waktu paruh distribusi lebih panjang, sehingga efek antikonvulsan lebih lama dan mempunyai efek samping berupa depresi pernapasan lebih jarang dibandingkan diazepam. ${ }^{12-14}$

\section{Metoda}

Penelitian merupakan uji klinis acak terbuka, berlangsung di Instalasi Gawat Darurat (IGD) Rumah Sakit Cipto Mangunkusumo Jakarta dan Rumah Sakit Umum (RSU) Tangerang. Subyek penelitian adalah anak berusia 6 bulan sampai 6 tahun dengan kejang yang belum mendapat obat antikonvulsan. Pasien dengan penyakit hati atau ginjal yang dinilai secara klinis, tidak diikutsertakan. Persetujuan penelitian diperoleh dari Panitia Tetap Penilai Etik Penelitian FKUI. Persetujuan dari orang tua/wali subyek diperoleh setelah kejang teratasi, hal ini disebabkan karena kedaruratan pasien harus ditangani dengan segera. Sebanyak 44 pasien kejang diberikan lorazepam bukal $(\mathrm{n}=22)$ dan diazepam rektal $(\mathrm{n}=22)$ berdasarkan tabel randomisasi. Dosis lorazepam 0,05 $-0,1 \mathrm{mg} / \mathrm{kg}$ berat badan. Tablet lorazepam bukal terdiri dari 3 macam sediaan yaitu $0,5 \mathrm{mg}$ untuk pasien dengan berat badan $<10 \mathrm{~kg}$, tablet $1 \mathrm{mg}$ untuk berat badan $10-20 \mathrm{~kg}$ dan tablet $2 \mathrm{mg}$ untuk berat badan $>20 \mathrm{~kg}$. Diazepam rektal terdiri dari 2 macam sediaan yaitu $5 \mathrm{mg}$ untuk berat badan $<10 \mathrm{~kg}$ dan $10 \mathrm{mg}$ untuk berat badan $>10 \mathrm{~kg}$. Tablet lorazepam tersebut diletakkan di mukosa bukal dan akan larut dengan sendirinya dalam waktu \pm 20 detik. Diazepam rektal diberikan melalui dubur. Lama penghentian kejang dinilai dengan menggunakan stopwatch. Jika kejang tidak teratasi dalam 2 kali siklus pengobatan, maka penanganan kejang dilanjutkan sesuai dengan protokol tata laksana kejang. Parameter keberhasilan terapi pada penelitian ini adalah kemampuan obat untuk menghentikan kejang dan kecepatan obat menghentikan kejang. Analisis statistik dilakukan dengan menggunakan uji chi square dan Fisher serta untuk hasil penelitian dengan adanya nilai ekstrim digunakan uji Mann-Whitney. Secara statistik dianggap bermakna bila nilai $\mathrm{p}<0,05$.

\section{Hasil}

Karakteristik demografik subyek penelitian pada kedua kelompok tidak berbeda bermakna seperti tertera pada Tabel 1.

Karakteristik klinis yang dijumpai pada subyek penelitian juga tidak berbeda bermakna antara kedua kelompok. Karakteristik klinis ini tertera pada Tabel 2.

Penyebab kejang pada kedua kelompok sebagian besar adalah kejang demam kompleks, diikuti dengan ensefalitis, kejang demam sederhana, meningitis purulenta, meningitis tuberkulosis, dan ensefalopati metabolik. Pada penelitian ini didapatkan efektivitas lorazepam bukal dalam menghentikan kejang (18 dari 22 pasien) sama dengan diazepam rektal (20 dari 22 pasien) dengan nilai $\mathrm{p}=0,664 ; 95 \%$ IK $0,71-1,14$. (Tabel 3)

Tabel 1. Sebaran karakteristik demografik menurut kelompok penelitian

\begin{tabular}{|c|c|c|c|}
\hline \multirow{2}{*}{$\begin{array}{l}\text { Karakteristik } \\
\text { demografik }\end{array}$} & \multicolumn{2}{|c|}{ Kelompok penelitian } & \multirow[b]{2}{*}{$\mathrm{P}$} \\
\hline & $\begin{array}{l}\text { Lorazepam } \\
\quad(n=22)\end{array}$ & $\begin{array}{c}\text { Diazepam } \\
(\mathrm{n}=22)\end{array}$ & \\
\hline \multicolumn{4}{|l|}{ Jenis kelamin } \\
\hline Laki-laki & 15 & 16 & 1,000 \\
\hline Wanita & 7 & 6 & \\
\hline \multicolumn{4}{|c|}{ Kelompok usia (tahun) } \\
\hline$<1$ & 4 & 6 & \\
\hline$\geq 1-3$ & 12 & 11 & 0,924 \\
\hline$>3$ & 6 & 5 & \\
\hline
\end{tabular}


Tabel 2. Sebaran karakteristik klinis menurut kelompok penelitian

\begin{tabular}{lccc}
\hline Karakteristik & \multicolumn{3}{c}{ Kelompok penelitian } \\
klinis & $\begin{array}{c}\text { Lorazepam } \\
(\mathbf{n}=22)\end{array}$ & $\begin{array}{c}\text { Diazepam } \\
(\mathbf{n}=22)\end{array}$ & \\
\hline Status gizi & & & \\
$\quad$ Baik & 10 & 9 & 1,000 \\
$\quad$ Kurang & 12 & 13 & \\
Jenis kejang * & & & \\
$\quad$ Fokal & 0 & 3 & 0,233 \\
$\quad$ Umum & 22 & 19 & \\
Kelompok diagnosis & & & \\
$\quad$ Kejang demam & 15 & 17 & 0,735 \\
$\quad$ Kejang lain-lain & 7 & 5 & \\
Umur** /bulan & $24,8 \pm 17,3$ & $27,3 \pm 18,8$ & 0,796 \\
Rasio BB/TB & $87,9 \pm 12,3$ & $89,4 \pm 9,2$ & 0,645 \\
Lama kejang (menit) & $13,4 \pm 12,3$ & $10,4 \pm 7,9$ & 0,396 \\
Frekuensi kejang (kali) & $2,6 \pm 2,0$ & $2,7 \pm 1,8$ & 0,685 \\
\hline
\end{tabular}

Ket : * Uji Mutlak Fisher

**Uji Mann Whitney

Tabel 3. Proporsi kemampuan menghentikan kejang antara lorazepam dan diazepam menurut kelompok penelitian

\begin{tabular}{lccc}
\hline Kelompok penelitian & \multicolumn{2}{c}{ Hasil terapi } & \multirow{2}{*}{ Jumlah } \\
\cline { 2 - 3 } & Berhasil & Gagal & \\
\hline Lorazepam & 18 & 4 & 22 \\
Diazepam & 20 & 2 & 22 \\
\hline Jumlah & 38 & 6 & 44 \\
\hline
\end{tabular}

$\mathrm{p}=0,664$

$95 \% \mathrm{IK}=0,71-1,14$

Lorazepam bukal dapat menghentikan kejang pada seluruh kasus kejang demam yaitu sebanyak 15 pasien, sedangkan pada kasus kejang lain yang bukan kejang demam hanya berhasil menghentikan kejang pada 3 dari 7 pasien. Diazepam rektal dapat menghentikan kejang pada seluruh kasus kejang demam yaitu pada 15 pasien dan pada kasus kejang lain berhasil menghentikan 5 dari 7 pasien kejang. Untuk lama penghentian kejang yang dinilai sejak obat diberikan sampai kejang berhenti didapatkan bahwa diazepam rektal lebih cepat dalam menghentikan kejang $(82,3 \pm 119,0)$ detik dibandingkan lorazepam bukal $(128 \pm 97,4)$ detik. Secara statistik berbeda bermakna $(\mathrm{p}=0,008)$.
Pada kedua kelompok penelitian didapatkan nilai ekstrim sehingga perlu ditampilkan keberhasilan obat pada satu kali siklus pengobatan. Lama penghentian kejang yang berhasil pada satu kali siklus pengobatan, diazepam rektal juga lebih cepat dalam menghentikan kejang $(44,7 \pm 22,1)$ detik dibandingkan lorazepam bukal $(92,2 \pm 53,5)$ detik, perbedaan ini bermakna ( $\mathrm{p}$ $=0,002)$. Efek samping dari kedua kelompok penelitian, baik diazepam maupun lorazepam, tidak dijumpai pada penelitian ini.

\section{Diskusi}

Selama penelitian diperoleh 44 subyek penelitian dengan usia rerata subyek pada kelompok lorazepam penelitian ini didapatkan 24,8 bulan dan 27,3 bulan pada kelompok diazepam, sedangkan jenis kelamin laki-laki lebih banyak dibandingkan dengan perempuan. Adapun diagnosis terbanyak pada penelitian ini adalah kejang demam. Hal ini sesuai dengan etiologi tersering kejang pada anak adalah kejang demam dan awitan kejang demam rata-rata berusia 17-23 bulan serta lebih sering terjadi pada laki-laki. ${ }^{15}$

Obat-obatan golongan benzodiazepin dipercaya dapat mengontrol kejang dengan baik. ${ }^{2-4}$ Lorazepam dan diazepam mempunyai kemampuan yang sama dalam mengatasi kejang, dan dari jumlah siklus pengobatan ternyata tidak berbeda $(\mathrm{p}=0,719)$. Hasil penelitian ini berbeda dengan penelitian yang mempergunakan lorazepam intravena yang dibandingkan dengan diazepam intravena. Alldredge BK, dkk. ${ }^{16}$ mendapatkan pemberian lorazepam intravena lebih efektif menghentikan kejang dibandingkan diazepam intravena (rasio odds 1,9; 95\% IK 0,9-4,3), dan penelitian Cock HR, $\mathrm{dkk}^{17}$ yang menunjukkan bahwa pemberian lorazepam intravena lebih baik dalam mengatasi kejang. Penelitian Yager, dkk dan Wassmer, dkk menggunakan lorazepam tablet tidak menggunakan kelompok kontrol. Pada penelitian Yager dkk, dari 10 subyek penelitian didapatkan 8 anak memberikan respons baik dan 2 anak memberikan respons parsial. Sedangkan Wassmer dkk menyimpulkan lorazepam efektif menghentikan kejang lama dan kejang berulang pada anak dan dapat digunakan sebagai alternatif pilihan terhadap diazepam rektal. ${ }^{9,10}$

Hasil terapi lorazepam menurut kelompok diagnosis, secara klinis terdapat perbedaan antara kelompok kejang demam dan kelompok kejang 
lainnya, bukan kejang demam. Kelompok kejang demam secara keseluruhan dapat diatasi dengan pemberian lorazepam, sedangkan pada kelompok kejang lain, lorazepam gagal mengatasi kejang pada 4 pasien, 2 pasien membutuhkan siklus pengobatan 2 kali dan 1 pasien dengan siklus pengobatan 1 kali. Demikian pula dengan hasil terapi diazepam menurut kelompok diagnosis, secara klinis terdapat pula perbedaan antara kelompok kejang demam dan kelompok kejang lain. Dari kelompok diazepam, pasien kejang demam secara keseluruhan dapat diatasi dengan pemberian diazepam, sedangkan pada kejang lain, diazepam gagal mengatasi kejang pada 2 pasien, 2 pasien membutuhkan siklus pengobatan $2 \mathrm{kali}$, dan 3 pasien membutuhkan siklus pengobatan 1 kali.

Kejang merupakan kedaruratan yang harus segera diatasi, oleh karena itu penghentian kejang harus dilakukan sesegera mungkin. Berdasarkan hal ini maka parameter keberhasilan pada penelitian ini, selain kemampuan obat untuk menghentikan kejang juga kecepatan obat dalam mengontrol kejang sangatlah penting. Pada penelitian ini rerata lama penghentian kejang $(120,8 \pm 97,4$ menit; median 90, range 30-360) untuk kelompok lorazepam dan $(82,3 \pm 119,0$ menit; median 45 , range $25-480)$ pada kelompok diazepam; perbedaan ini bermakna. Demikian pula dengan rerata lama penghentian kejang pada satu kali siklus pengobatan, $(92,2 \pm 53,5$ menit; median 60, range 30-180) untuk kelompok lorazepam dan $(44,7 \pm 22,1$ menit; median 45 , range 25-120) untuk kelompok diazepam; perbedaan ini bermakna. Penghentian kejang untuk masing-masing kelompok perlu dibedakan antara 1 kali siklus pengobatan dan 2 kali siklus pengobatan, karena didapatkan nilai ekstrim pada hasil dengan 2 kali siklus pengobatan.

Dari kedua parameter yang digunakan untuk menilai efektivitas obat golongan benzodiazepin dalam menghentikan kejang kedua memperlihatkan efektivitas yang sama, namun untuk kecepatan penghentian kejang diazepam rektal memiliki keunggulan dibandingkan dengan lorazepam bukal. Pemberian obat, baik melalui bukal maupun rektal memiliki absorpsi yang cepat; karena obat terhindar dari first-pass effect. ${ }^{8,18}$ Adapun faktor yang diduga mendukung kecepatan diazepam rektal dalam mengontrol kejang adalah sifat fisikokimiawi diazepam yang lebih lipofilik dibandingkan dengan lorazepam, sehingga lebih mudah menembus sawar darah otak dan awitan kerja menjadi lebih cepat. ${ }^{6,12}$ Hal lain yang mendukung keadaan ini adalah bentuk cair sediaan diazepam dibandingkan bentuk tablet lorazepam. Bentuk tablet lorazepam memerlukan waktu \pm 20 -30 detik untuk larut dan kemudian diabsorpsi, sedangkan sediaan diazepam yang sudah berbentuk cair dapat langsung diabsorpsi. Efek samping tersering dari lorazepam sama seperti golongan benzodiazepin lain, yaitu mual, muntah, hipotensi, hingga depresi pernapasan, namun hal ini jarang terjadi jika dibandingkan depresi pernapasan akibat pemakaian obat antikonvulsan golongan barbiturat seperti fenobarbital. ${ }^{12,13}$ Diazepam mempunyai waktu paruh yang lebih lama sehingga lebih potensial untuk terakumulasi pada pengulangan terapi dibandingkan lorazepam. ${ }^{6,13}$ Pada penelitian Norris, dkk ${ }^{19}$ yang menggunakan diazepam baik intravena maupun rektal mendapatkan kejadian depresi pernapasan 9\%. Sedangkan Lacey, dkk. mendapatkan lorazepam aman digunakan pada anak dan remaja. ${ }^{20}$ Pada penelitian ini tidak ditemukan efek samping pada kedua kelompok sehingga dapat disimpulkan bahwa penggunaan lorazepam aman digunakan pada anak.

\section{Kesimpulan}

Lorazepam bukal dan diazepam rektal memiliki efektivitas yang sama dalam menghentikan kejang, namun diazepam rektal menghentikan kejang lebih cepat dibandingkan lorazepam bukal. Kedua obat tersebut menghentikan seluruh kasus kejang demam dan hanya sebagian kecil kasus kejang lainnya. Tidak ditemukan efek samping akibat pemakaian lorazepam bukal maupun diazepam rektal.

\section{Daftar Pustaka}

1. Haslam RHA. The nervous system. Dalam: Behrman RE, Kliegman RM, Jenson HB, penyunting. Nelson textbook of pediatrics. Edisi ke-16. Philadelphia: WB Saunders Company, 2000. h.1793-866.

2. Freedman SB, Powel EC. Pediatric seizures and their management in the emergency department. Clin Ped Emerg Med 2003; 4:195-206.

3. Tasker RC. Emergency treatment of acute seizures and status epilepticus. Arch Dis Child 1998; 79:78-83. 
4. Widodo DP. Algoritme penatalaksanaan kejang akut dan status epileptikus pada bayi dan anak. Dalam: Pusponegoro HD, Handryastuti S, Kurniati N., penyunting. Pediatric neurology and neuroemergency in daily practice. Pendidikan Kedokteran Berkelanjutan Ilmu Kesehatan Anak FKUI XLIX. Jakarta 27-28 Maret 2006. Badan Penerbit Ikatan Dokter Anak Indonesia, 2006. h. 63-9.

5. Rosenow F, Arzimanoglou A, Baulac M. Recent development in treatment of status epilepticus: a review. Epileptic Disord 2002; 4:S1-11.

6. Young CC, Prielipp RC. Benzodiazepines in the intensive care unit. Crit Care Clin 2001; 17:843-62.

7. Mangunatmadja I. Kejang pada anak. Dalam: Trihono PP, Syarif DR, Hegar B, Gunardi H, penyunting. Hot topics in pediatrics II. Pendidikan Kedokteran Berkelanjutan Ilmu Kesehatan Anak FKUI XLV. Jakarta 18-19 Februari; 2002. Jakarta: Balai Penerbit FKUI, 2002. h. 245-61.

8. Administration of drugs by the buccal route. Lancet 1987; 1:666-7.

9. Yager JY, Seshia SS. Sublingual lorazepam in childhood serial seizures. AJDC 1988; 142:931-2.

10. Wassmer E, Allen A, Bjelajac A, Weiss S. Sublingual lorazepam at home for the treatment of seizures in children. Arch Dis Child 2003; 88:A36 (abstrak).

11. American Academy of Pediatrics. Alternative routes of drug administration-advantages and disadvantages. Pediatrics 1997; 100:143-52.
12. Raj A, Seehan D. Benzodiazepines. Dalam: Schatzberg AF, Nemeroff CB, penyunting. Textbook of psychopharmacology. Edisi ke-3. Washington DC: American Psychiatric Publishing Inc, 2004. h. 371-89.

13. Manno EM. New management strategies in the treatment of status epilepticus. Mayo Clin Proc 2003; 78:508-18.

14. Scot RC, Neville BG. Pharmacological management of convulsive status epilepticus in children. Dev Med Child Neurol 1999; 41:207-10.

15. Daoud A. Febrile convulsion: review and update. J Pediatr Neurol 2004; 2:9-14.

16. Alldredge BK, Gelb AM, Isaacs SM, Corry MD, Allen F, Ulrich S, et al. A comparison of lorazepam, diazepam, and placebo for the treatment of out-of-hospital status epilepticus. N Engl J Med 2001; 345:631-7.

17. Cock HR, Schapira AH. A comparison of lorazepam and diazepam as initial therapy in convulsive status epilepticus. Q J Med 2002; 95:225-31.

18. Radde IC. Mechanisms of drug absorption and their development. Dalam: Radde IC, Mac Leod SM, penyunting. Pediatric pharmacology and therapeutics. Edisi ke-2. St. Louis: Mosby; 1993. h. 16-30.

19. Norris E, Marzouk O, Nunn A, Mc Intyre J, Choonara I. Respiratory depression in children receiving diazepam for acute seizure: a prospective study. Dev Med Child Neurol 1999; 41:340-3.

20. Lacey DJ, Singer WD, Horwitz SJ, Gilmore H. Lorazepam therapy of status epilepticus in children and adolescents. J Pediatr 1986; 108:771-4. 